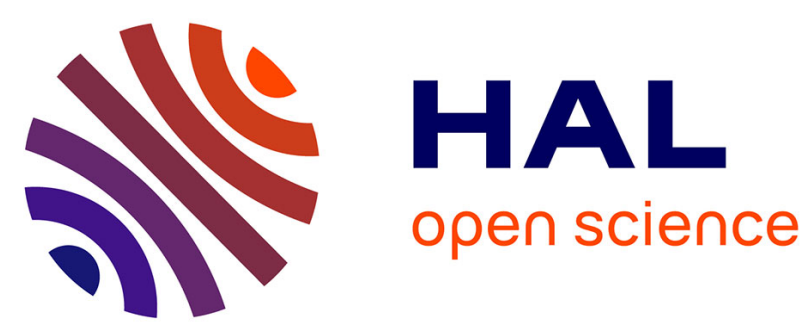

\title{
Seabird recovery and vegetation dynamics after Norway rat eradication at Tromelin Island, western Indian Ocean
}

\author{
Matthieu Le Corre, D. K. Danckwerts, David Ringler, Matthieu Bastien, S.
} Orlowski, C. Morey Rubio, David Pinaud, Thierry Micol

\section{- To cite this version:}

Matthieu Le Corre, D. K. Danckwerts, David Ringler, Matthieu Bastien, S. Orlowski, et al.. Seabird recovery and vegetation dynamics after Norway rat eradication at Tromelin Island, western Indian Ocean. Biological Conservation, 2015, 185, pp.85-94. 10.1016/j.biocon.2014.12.015 . hal-01207081

\section{HAL Id: hal-01207081 \\ https://hal.science/hal-01207081}

Submitted on 26 Apr 2016

HAL is a multi-disciplinary open access archive for the deposit and dissemination of scientific research documents, whether they are published or not. The documents may come from teaching and research institutions in France or abroad, or from public or private research centers.
L'archive ouverte pluridisciplinaire HAL, est destinée au dépôt et à la diffusion de documents scientifiques de niveau recherche, publiés ou non, émanant des établissements d'enseignement et de recherche français ou étrangers, des laboratoires publics ou privés. 


\title{
Seabird recovery and vegetation dynamics after Norway rat eradication at Tromelin Island, western Indian Ocean
}

\author{
M. Le Corre ${ }^{\mathrm{a}, *}$, D.K. Danckwerts ${ }^{\mathrm{a}, \mathrm{b}}$, D. Ringler ${ }^{\mathrm{a}, \mathrm{d}}$, M. Bastien ${ }^{\mathrm{a}}$, S. Orlowski ${ }^{\mathrm{a}}$, C. Morey Rubio $^{\mathrm{a}}$, D. Pinaud $^{\mathrm{c}}$, \\ T. Micol ${ }^{\mathrm{d}, \mathrm{e}}$ \\ a Laboratoire ECOMAR, FRE3560, Université de La Réunion, INEE-CNRS, 97715 Saint Denis messag cedex 9, France \\ ${ }^{\mathrm{b}}$ Department of Zoology and Entomology. Rhodes University, Grahamstown 6140, South Africa \\ ${ }^{c}$ CEBC, UMR7372, CNRS/Université de La Rochelle, 79360 Villiers en Bois, France \\ ${ }^{\mathrm{d}}$ TAAF, Rue Gabriel Dejean, 97410 Saint-Pierre, Reunion \\ ${ }^{\mathrm{e}}$ LPO, Fonderies Royales, 10 rue du Dr Pujos, 17305 Rochefort, France
}

\begin{abstract}
A B S T R A C T
Seabirds are notoriously sensitive to introduced mammalian predators and eradication programs have benefitted seabird populations and their habitats on numerous islands throughout the world. However, less evidence is available from the tropics as to the benefits of rat eradication. Here, we report the seabird recovery and vegetation dynamics on a small coralline island of the tropical western Indian Ocean, eight years after Norway rat (Rattus norvegicus) eradication. Two species of seabirds were breeding before rat eradication (red-footed and masked boobies, Sula sula and Sula, dactylatra) and, in both species, the number of breeding pairs had an apparent increase of $22-23 \%$ per year after rat eradication. Such a high annual growth rate cannot be achieved by auto-recruitment only and our data suggest that immigration from other source populations never occurred in at least one of these species. We suggest that it is rather due to a rapid increase in breeding success, which rapidly increased the observed number of breeders since birds remained in the available-for-counting-as-breeders group for much longer. Two other species, the white tern (Gygis alba) and the brown booby (Sula leucogaster) were recorded breeding in 2014. The former species has not bred on the island since 1856 and the latter has never bred on the island. Plant cover (monospecific formation of the ruderal herb Boerhavia diffusa) dramatically increased from less than $30 \%$ of surface coverage to more than $70 \%$. Although the initial restoration project was to eradicate all introduced mammals of the island simultaneously, house mouse (Mus musculus) eradication failed. Mouse density was high 8 years after rat eradication ( 32 mice/ha in dry season and 52 mice/ha in rainy season) but not higher than at a comparable tropical island of the region (Juan de Nova) where mice coexist with introduced black rats (Rattus rattus) and feral cats (Felis catus). These results are discussed in terms of the direct positive effects of rat eradication on seabirds and plants and the indirect positive effects of post-eradication seabird increase on soil manuring and vegetation recovery. Overall, our results show that on tropical islands, seabird and habitat recovery can be very rapid after rat eradication and should be implemented as a restoration tool wherever possible.
\end{abstract}

\section{Introduction}

Seabirds are notoriously sensitive to introduced predators, like rats (Towns et al., 2006; Jones et al., 2008). By preying on eggs and chicks, rats reduce breeding success (see for instance Thibault 1995; Pascal et al., 2008), which has long-term effects on bird recruitment, population dynamics, population size and breeding distribution (Ruffino et al., 2009). Rats are also able to

\footnotetext{
* Corresponding author.

E-mail address: lecorre@univ-reunion.fr (M. Le Corre).
}

prey on adults of the smallest seabird species, like storm-petrels or auklets (Whitworth et al., 2005; De Leon et al., 2006; Jones et al., 2008), which has an even greater impact on the population dynamics of these species. Numerous seabird populations are threatened by or have become locally extinct as a consequence of rat predation (De Leon et al., 2006; Jones et al., 2008). But considerable effort has been made to eradicate rats from islands over the last four decades, thus promoting the conservation and recovery of native flora and fauna (Towns and Broome 2003; Howald et al., 2007; Aguirre-Munoz et al., 2008). The positive effects of these eradications are numerous and have been well documented in 
temperate regions (see for instance Towns and Broome 2003; Jones 2010a). For seabirds, the removal or control of rats on islands increases breeding success and population size (Whitworth et al., 2005; Smith et al., 2006; Pascal et al., 2008; Jones 2010a; Bourgeois et al., 2013). New species, including those previously driven to local extinction, can eventually return if the restored islands are within the prospecting range of unsettled adults (Micol and Jouventin, 2002; Buxton et al., 2014), or if populations have been actively reintroduced (Miskelly et al., 2009).

As mesopredators and aggressive competitors, rats can also regulate mouse populations on islands where both alien mammals have been introduced (Caut et al., 2007). As such, rat eradication can result in the release of mouse populations, if mice are not eradicated in the same time, which can lead to increased mouse damage to seabirds, plants or insects (Caut et al., 2007; Witmer et al., 2007; Ruscoe et al., 2011).

Rats can also have detrimental effects on native vegetation by direct consumption of the plants, seedlings and seeds (Mulder et al., 2009). On the other hand, seabirds can also positively affect island vegetation by soil manuring, which boosts the growth of nitrophilous species (Smith 1979; Wainright et al., 1998; Anderson and Polis 1999 and see the review of Ellis 2005). On islands functionally dominated by seabirds, rats can have indirect and often cascading impacts on ecosystem functioning, by depleting seabird densities and can thus disrupt across-ecosystem nutrient subsidies (Fukami et al., 2006; Towns et al., 2009; Mulder et al., 2009; Jones 2010b).

Although rats have been introduced to more than $80 \%$ of the island groups of the world, including many in the tropics (Varnham, 2010), the effects of these predators on tropical seabirds are less documented than on islands of high latitudes (Jones et al., 2008; Varnham, 2010, but see Ringler et al., 2015). Furthermore, fewer attempts have been made to eradicate rats from tropical islands and the success rate of these efforts often lower than on temperate islands (Holmes et al., 2015). When successful, the effects of these eradications on tropical island biodiversity and ecosystems are rarely reported (Russell and Holmes, 2015).

In this paper we report the dynamics of the seabird community of Tromelin Island, a small (100 ha) remote coralline island of the tropical western Indian Ocean, where Norway rats (Rattus norvegicus) were successfully eradicated in December 2005. The initial plan was to eradicate both Norway rats and house mice (Mus musculus) over the same time period but mouse eradication failed (see below). We estimated mouse density 7-8 years after rat eradication to assess the current or potential impact of mice on Tromelin's terrestrial ecosystems. We also studied the changes to vegetation cover and diversity after rat eradication, so to investigate any direct effects of rats and mice on vegetation or any indirect effects of seabird recovery on vegetation after rat eradication.

\section{Material and methods}

\subsection{A short history of Tromelin Island}

Tromelin $\left(15^{\circ} 53^{\prime} \mathrm{S}, 54^{\circ} 31^{\prime} \mathrm{E}\right.$, Fig. 1$)$ is a 100 ha flat coralline island of the western Indian Ocean. Tromelin has a typical tropical marine climate with a wet and warm season from December to April and a dry and cool season from May to November. Average annual rainfall ranges from 1000 to $1500 \mathrm{~mm}$, more than half of which occurs between January and March. The average temperatures range from $20^{\circ} \mathrm{C}$ during the dry season to $26^{\circ} \mathrm{C}$ during the wet season (Météo France pers. comm.). The island is frequently hit by tropical storms and cyclones during the wet season.

Tromelin originally had a diverse and abundant seabird community, with between six to eight breeding species (great and lesser frigatebirds Fregata minor and Fregata ariel, sooty terns Onychoprion fuscatus, white terns Gygis alba, red-footed and masked boobies Sula sula and Sula dactylatra, brown and lesser noddies Anous stolidus and Anous tenuirostris, see le Corre 1996). The island is thought to have remained undisturbed until July 1761 when the ship l'Utile, which was doing illegal slave trading between Madagascar and the Mascarene Archipelago (Mauritius, Réunion and Rodrigues), shipwrecked with at least 183 people on board (including 60 slaves and 123 French mariners). Part of this group managed to leave the island two months later using a self-made boat but the slaves were left on the island and "forgotten." They lived there for 15 years and fed on marine turtles, fish and seabirds. Finally in November 1776 the Chevalier de Tromelin, captain of the ship La Dauphine, rescued eight survivors including seven women and an 8-month-old baby (Laroulandie and Lefevre 2013).

A recent archaeozoological analysis of almost 18,000 bird bones found during an archeological excavation campaign conducted by Guérout and Romon, has shown that at least 5 species of seabird were present on the island at the time of the wreck and were hunted by the forgotten slaves (Laroulandie and Lefevre 2013). Sooty terns and brown noddies, among others, appear to have been particularly abundant. The excavations have also shown that a tropicbird (probably the red-tailed tropicbird Phaethon rubricauda) was regularly hunted and so probably also bred there at the end of the 18 th century.

The island remained unvisited until December 1856 when an English hunter, Layard, visited the island. He mentioned 8 seabird species among which 6 where breeding (Brooke 1981). The next visit was almost one century later (1954), when French meteorologists set up a meteorological station, which remains operational today. Only 4 breeding seabird species were recorded at the time of this visit, the great and lesser frigatebirds and the red-footed and masked boobies (Brygoo 1955). Forty years later, the two species of frigatebird were no longer breeding on the island, probably as a consequence of human disturbance at colonies as people permanently occupied the island from 1954 (Le Corre 1996). For a complete description of Tromelin and its past and present avifauna see le Corre (1996) and Laroulandie and Lefevre (2013).

The introduction of rats and mice at Tromelin is not well documented but mice were present since at least 1859 (Russell and Le Corre, 2009). Both rats and mice were present in 1954 (Brygoo 1955). It is worth noting that a single bone of a small mammal was found during the archeological excavations mentioned above (Laroulandie pers. comm.). This suggests that rats and/or mice may have been introduced during the wreck of l'Utile or possibly even before.

\subsection{Rat and mouse eradication method}

The eradication attempt was performed from 5 December 2005 to 2 January 2006 . We used an extruded chocolate flavoured, blue block bait (Pestoff Rodent Blocks) containing $0.02 \mathrm{~g} / \mathrm{kg}$ brodifacoum for use in bait stations and $10 \mathrm{~mm}$ diameter pellet baits (Pestoff Rodent Bait 20R) with $0.02 \mathrm{~g} / \mathrm{kg}$ brodifacoum for hand broadcast. A total of $25 \mathrm{~kg}$ of blocks were used in bait stations and 1 tonne of pellets $(10 \mathrm{~kg} / \mathrm{ha})$ was broadcasted manually in a single application throughout across the island. This broadcast application rate is in the lower range of what is generally done in such operations (see for instance Keitt et al., 2015; Russell and Holmes, 2015). The bait stations were regularly placed over a $100 \times 100 \mathrm{~m}$ grid on the whole island.

Eighty-one stations, with one bait block each, were set during a single pass of the entire island and each was then revisited daily from 7 December to 1 January, over which time it was noted whether each bait had been partially or totally eaten by rats or mice. Baits were replaced only if necessary (with blocks or pellets). 


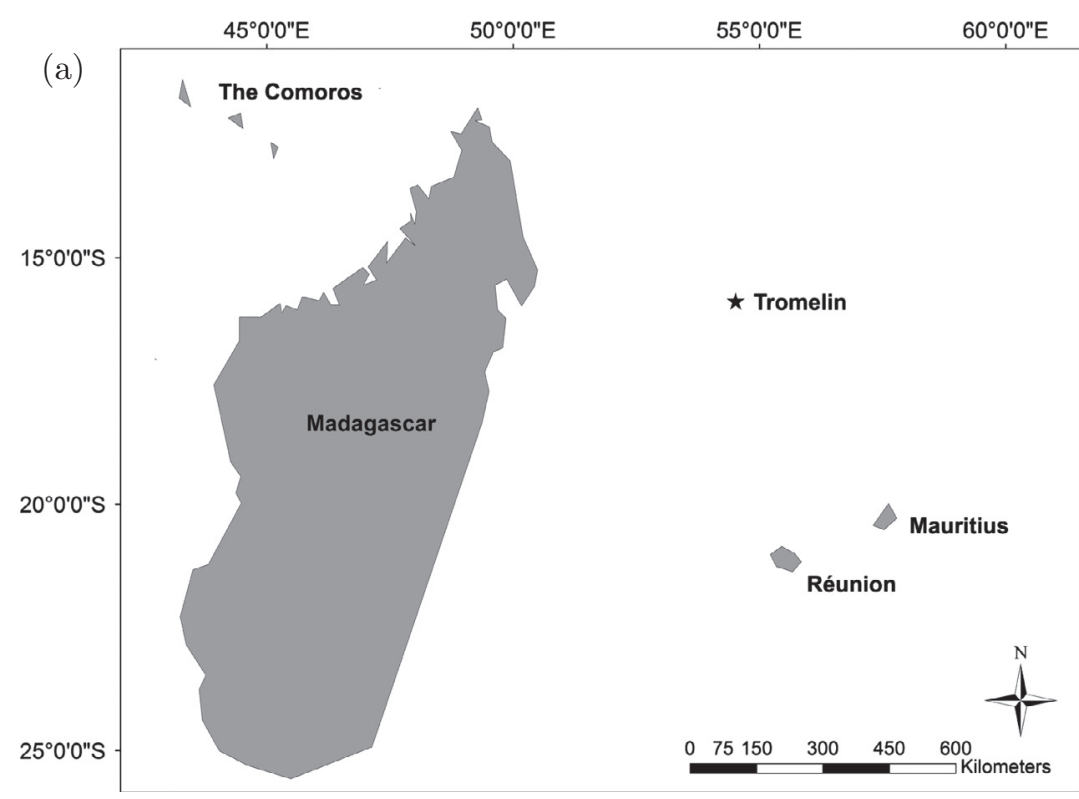

(b)

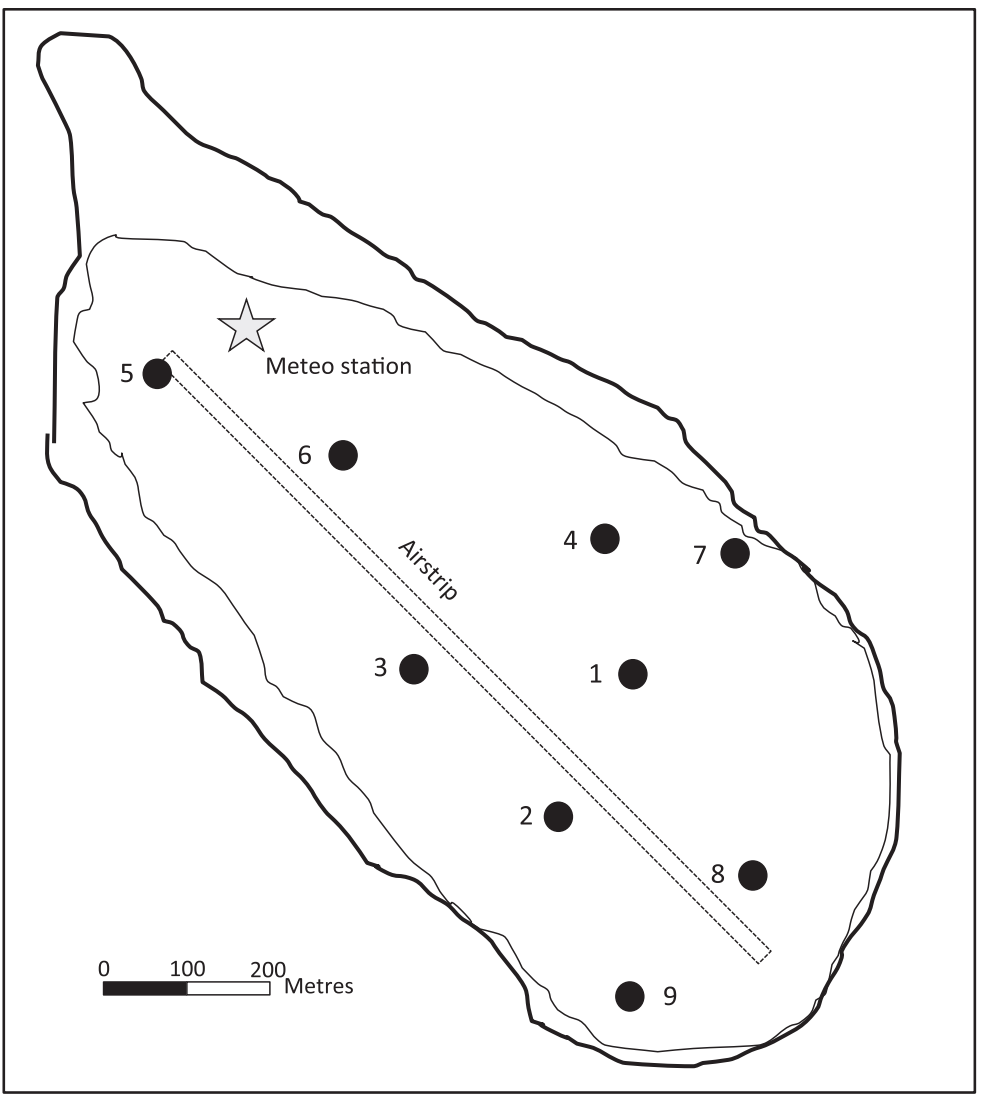

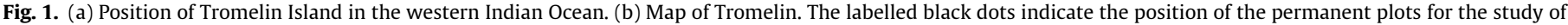
the vegetation cover.

Hermit crabs (Coenobita sp.) are abundant on the island, so baits were positioned in PVC tubes that were fixed onto poles, $20 \mathrm{~cm}$ above the ground, thus avoiding non-target bait predation by hermit crabs. We verified, using INRA traps (BTTM Mécanique, Besançon, France), that both rats and mice could still reach the tubes.

There are very few potential non-target species on Tromelin, considering warm-blood species only (birds and mammals). There are no mammals, other than rats and mice, and no breeding birds except the two boobies. Non-breeding birds occasionally visit the island (mostly ruddy turnstones Arenaria interpres and whimbrel Numenius phaeopus) but they are in low numbers. However, we controlled for non-target species mortality throughout the eradication process. We performed searches for dead and/or dying birds by walking daily (from 5 December 2005 to 2 January 2006) across the entire island focusing our attention around each bait station. 


\subsection{Eradication confirmation}

No rats have been seen or captured after the eradication campaign, although the island has been regularly visited by ship and plane and continuously inhabited by a minimum of 4 people since that operation. To confirm the absence of rats, we conducted two systematic trapping operations in August 2012 and May 2013. During these stays, we deployed 60 live traps during 30 nights and recorded all captures. Each trap was set on a small table reachable by rats and mice but not by hermit crabs.

\subsection{Estimation of mouse density 8 years after rat eradication}

We estimated mice density $(D)$ in August 2012 (dry season) and May 2013 (end of rainy season) using maximum-likelihood spatially explicit capture-recapture methods (ML SECR) implemented in $\mathrm{R}$ (package SECR, Borchers and Efford, 2008). During each session, 30 (in 2012) and 49 (in 2013) INRA traps (BTTM Mécanique, Besançon, France) were set following $6 \times 5$ and $7 \times 7$ grids at $10 \mathrm{~m}$ intervals (respectively 0.2 ha and 0.36 ha). For 7 consecutive days, each trap was baited and set in the evening $(5 \mathrm{pm})$ and checked the next morning ( $7 \mathrm{am}$ ). Mice captured for the first time were sexed, weighed, ear-tagged and released. We then recorded the tag number and location on the grid for each recapture event.

In our analyses, we assumed a Poisson distribution of range centres (i.e. random) with a hazard detection function parameterised by $g 0$ (the probability of detection when trap and range centre coincide), $\sigma$ (the spatial scale of the detection function) and $z$ (the shape parameter of the detection function). Removals in the population (i.e. accidental deaths during trapping) were assigned a known capture history of 0 with a probability equals 1 following death. A maximised likelihood was used to estimate density, and models were compared using an AIC framework. We allowed density, $D$, probability of capture, $g 0$, and spatial scale parameter, $\sigma$, to vary between sessions (August 2012 vs. May 2013). We tested these different models with $z$ variable or constant between season and the best model was always with $z$ constant.

\subsection{Seabird census}

A census of seabirds, including breeding population size estimations for every species, was conducted during each field visit to the colony. In order to detect breeding of new seabird species, we noted all seabird species present on the island and recorded their displaying or breeding behaviour, if any.

Both species of boobies breed all year round (Le Corre 1996 and unpublished data). The red-footed booby is non-seasonal (laying may occur at any time of the year) and the masked booby is loosely seasonal (most eggs being laid between June and November (Le Corre 1996 and unpublished data). Because of this lack of synchrony between pairs, it is difficult to make an accurate estimation of the number of breeding individuals when one considers only incubating or chick-rearing birds. Thus, we defined a pair as a couple of adults or a single bird seated on a nest, whatever the content of the nest. This includes courting, incubating and chick-rearing birds. Both species are monogamous and share parental care through the breeding season. We recorded the breeding status for every pair among one of the following: adult or pair on an empty nest (guarding a site, displaying or building a nest), adult or pair incubating an egg, adult or pair brooding a downy chick or rearing an older chick, or a lone chick at a nest site. Each nest or group of nests was marked in the field using a plastic ribbon and georeferenced with a Global Positioning System (GPS). The birds, which were not in association with any nest at the time of each field excursion, were disregarded. This includes non-breeding adults that frequently roost in specific places of the island and juveniles and subadult birds which remain around the colony but which are no longer dependent on adults.

The red-footed booby is polymorphic on Tromelin Island, where around $2 / 3$ of the adults are of the white-tailed white morph and 1 / 3 are of the white-tailed brown morph (Le Corre 1999). This population is the only current polymorphic population of red-footed boobies of the Indian Ocean (Le Corre 1999); all other populations are composed almost entirely of white (Aldabra, Cosmoledo, Saint Brandon) or brown birds (Europa). We estimated the proportion of each morph among the breeding adults, during each of our field visits, so as to detect any immigration from one of the monomorphic populations of the western Indian Ocean. During the first visit to a nest occupied by a lone breeding adult, we labelled the nest, georeferenced it and noted the colour morph of the adult. We marked the breast of the bird (using weather proof orange paint and a one metre long pole), thus permitting individual recognition from a distance. During the following visits, we then noted any changeover. If a changeover had occurred (presence of an adult with no colour mark) we noted the second colour morph.

\subsection{Seabird population dynamics}

Masked and red-footed boobies had a very rapid numerical response after rat eradication (see Section 3). In order to explore the possible causes of this dynamics we built a matrix population model using demographic parameters available for the red-footed booby in the literature (Dearborn et al., 2001 and Cubaynes et al., 2011 and see Appendix A for the matrix and demographic rates used in the model). We first calculated the annual growth rate of this population, assuming a closed population (no immigration or emigration), a stable environment (no inter-annual changes in demographic rates) and a high breeding success following rat eradication. Secondly, we explored the possibility that rat eradication, by abruptly increasing the breeding success, dramatically increased the observed number of breeding pairs, because birds would remain in the "available-for-counting-as-breeders group" much longer (see Section 3 for details). The matrix population modelling and growth rate calculation were done with the software ULM (Unified Life Models, Legendre and Clobert 1995).

\subsection{Vegetation survey}

The native vegetation of Tromelin Island is very simple and composed of only one species of littoral native shrub (Tournefortia argentea) and less than 10 species of herbs (Le Corre 1996; Gigord pers comm.). A few coconut trees were planted during the second half of the 20th century but they are restricted to the surroundings of the meteorological station. Nine permanent plots of $10 \times 10 \mathrm{~m}$ each were defined on various places of the island (Fig. 1). Each was georeferenced with a GPS and marked in the field by piles of stones and metal stakes. Each plot was monitored once in December 2005 (just before the rat eradication campaign) and then in May 2006, August 2012 and May 2013. As some of the field visits were very short (half a day, when a military plane visited the island for the normal changeovers of the permanent staff) we designed a rapid assessment method to measure changes in vegetation cover. For each field visit and for each permanent plot, we estimated the total vegetation cover, the number of strata (herbaceous or shrubs) and the strata cover, the average height of the vegetation and the species present. Photographs were also taken of each plot at each visit facilitating the estimation of complete vegetation cover. 


\section{Results}

\subsection{Non-target species and rat and mice densities after eradication}

We did not find any non-target species poisoned by the baits during the operation. No rats were caught subsequent to the eradication effort in December 2005, thus indicating successful eradication. No mice were seen during the first months after eradication but they reappeared 6 months later (Météo France pers. comm.), confirming that their eradication had failed. Spatially explicit capture-recapture models were constructed, allowing $D, g 0$, and $\sigma$ to vary with session. The model where $D$ and $\sigma$ varied with session and $g 0$ was constant had greatest weight (56\%, Table 1$)$. Estimates for both sessions are presented for the strongest supported model (Table 2). Density significantly increased between August 2012 (31.5 mice ha $\mathrm{ha}^{-1}$, 95\% CI: 19.5-51.1 mice ha ${ }^{-1}$ ) and May 2013 (52.2 mice ha ${ }^{-1}, 95 \%$ CI: 38.8-70.2 mice ha ${ }^{-1}$ ).

\subsection{Seabird recovery}

Fig. 2 presents the evolution of the number of pairs of masked and red-footed boobies counted at Tromelin between 1954 and 2013. At the time of rat eradication (December 2005) there were 130 and 224 pairs of red-footed boobies and masked boobies, respectively. Less than 8 years later (May 2013), red-footed and masked Booby populations had grown to between 855 and 1090 pairs, indicating an average apparent population growth of $+23 \%$ and $+22 \%$ per year for each species, respectively.

The population of red-footed boobies remained polymorphic during the study with no changes in morph proportions. In December 2005, among 124 breeding adults for which the colour morph was documented, $66 \%$ were of the white-tailed white morph and $34 \%$ were of the white-tailed brown morph. In August 2012, among 625 breeding adults for which colour morph was noted, there was 65.4\% white-tailed white morph and $33.6 \%$ white-tailed brown morph. Similarly in May 2013, among 1335 breeding adults for which the colour morph was noted, $65 \%$ were of the white-tailed white morph and 35\% were of the white-tailed brown morph. These results clearly show that the proportion of colour morphs remained stable since at least 1954 (see Le Corre 1999). As this population is the only one to be polymorphic in the western Indian Ocean, this trend suggests that no (or very few) birds immigrated to Tromelin from other colonies since rats were eradicated from the island.

Using the matrix population model shown in Appendix A, we explored the effects of rat eradication on the population dynamics of red-footed and masked boobies. We first investigated the effects of an increase in breeding success. We have no estimate of breeding success of both species of boobies at Tromelin Island before and after rat eradication, so we used available information obtained from the rat free Tern island, Hawaii, where the breeding success of red-footed boobies has been monitored from 1980 to 1998 (Dearborn et al., 2001).

The output of this model was a long-term change of the population growth rate from 0.968 before rat eradication to 1.040 after
Table 2

Estimates of $D, g 0$ and $\sigma$ for mice trapping sessions of August 2012 and May 2013.

\begin{tabular}{lllll}
\hline & Mean & SE & LCL & UCL \\
\hline$D$ & & & & \\
Aug. 2012 & 31.5 & 7.8 & 19.5 & 51.1 \\
May 2013 & 52.2 & 7.9 & 38.8 & 70.2 \\
g0 & & & & \\
Aug. 2012 & 0.289 & 0.044 & 0.210 & 0.383 \\
May 2013 & 0.289 & 0.044 & 0.210 & 0.383 \\
$\sigma$ & & & & \\
Aug. 2012 & 8.68 & 1.29 & 6.48 & 11.62 \\
May 2013 & 6.19 & 0.71 & 4.93 & 7.77 \\
\hline
\end{tabular}

$\overline{\text { SE standard error, LCL and UCL lower and upper 95\% confidence limits, respectively. }}$

rat eradication. However, because of the delayed maturity (most birds start to breed at the age of 6 years, see Cubaynes et al., 2011 and Appendix A), this change started to happen only 6 year after rat eradication (Fig. 3a). Thus the output of this model is not consistent to what we observed at Tromelin Island. More precisely, the theoretical annual growth rate of only $4 \%$ per year, starting 6 years after rat eradication, is much lower than what we observed (22-23\% per year soon after rat eradication).

As immigration is very unlikely, at least for the red-footed booby (see above), we explored the possibility that rat eradication increased the proportion of breeding adults present at any given time in the colony. The rationale for this is as follows. When rats were present, the breeding success was probably low and the number and proportion of failed breeders were probably very high. Although some of these failed breeders may re-lay after a first failure, we can reasonably assume that most failed breeders simply left their nesting places and gathered at the roosts of non-breeding birds or dispersed out to sea. As non-breeders were not counted during our snapshot censuses, these birds were simply not counted. Once rats had been eradicated, the breeding success probably increased rapidly, resulting in more breeding adults staying at their breeding places and thus a better detectability of these adults during our censuses.

We modelled this post-eradication process by increasing $\alpha_{a d}$, the proportion of adults that breed after rat eradication, from $20 \%$ before rat eradication to $90 \%$ after rat eradication. The population dynamics generated by this model is shown in Fig. 3b. As expected, the breeding population increased rapidly just after rat eradication as a consequence of an increased number of successful breeders. This rapid increase was followed by a slight decrease in breeding population during 5 years (a time-lagged effect of the low rat-induced breeding success inducing low recruitment) and then a slow increase after this time lag, due to an enhanced recruitment of the birds produced after rat eradication (Fig. 3b). This is more consistent with what we observed at Tromelin Island as it has the potential to explain the very high apparent annual growth rate observed between 2005 and 2013.

Eleven other species of seabird have been observed on the island in 2012 and 2013, suggesting that some of them may breed in the future (see Table 3 for details). Indeed, two of them, the white tern (G. alba) and the brown booby (Sula leucogaster) started to breed in

Table 1

Model results of mice detection function for covariate (session) of density $(D)$, the scale parameter $(\sigma)$ and the probability of capture at the home range centre ( $g 0$ ).

\begin{tabular}{|c|c|c|c|c|c|c|c|}
\hline$D$ & g0 & $\sigma$ & Npar & Log likelihood & $\mathrm{AICc}$ & Rank & \% Weight \\
\hline$\sim$ Session & Constant & $\sim$ Session & 6 & -1238.52 & 2489.91 & 1 & 56 \\
\hline$\sim$ Session & $\sim$ Session & $\sim$ Session & 7 & -1238.46 & 2492.09 & 2 & 19 \\
\hline$\sim$ Session & $\sim$ Session & Constant & 6 & -1240.21 & 2493.28 & 3 & 10 \\
\hline Constant & $\sim$ Session & $\sim$ Session & 6 & -1240.29 & 2493.44 & 4 & 9 \\
\hline$\sim$ Session & Constant & Constant & 5 & -1242.12 & 2494.86 & 5 & 5 \\
\hline
\end{tabular}




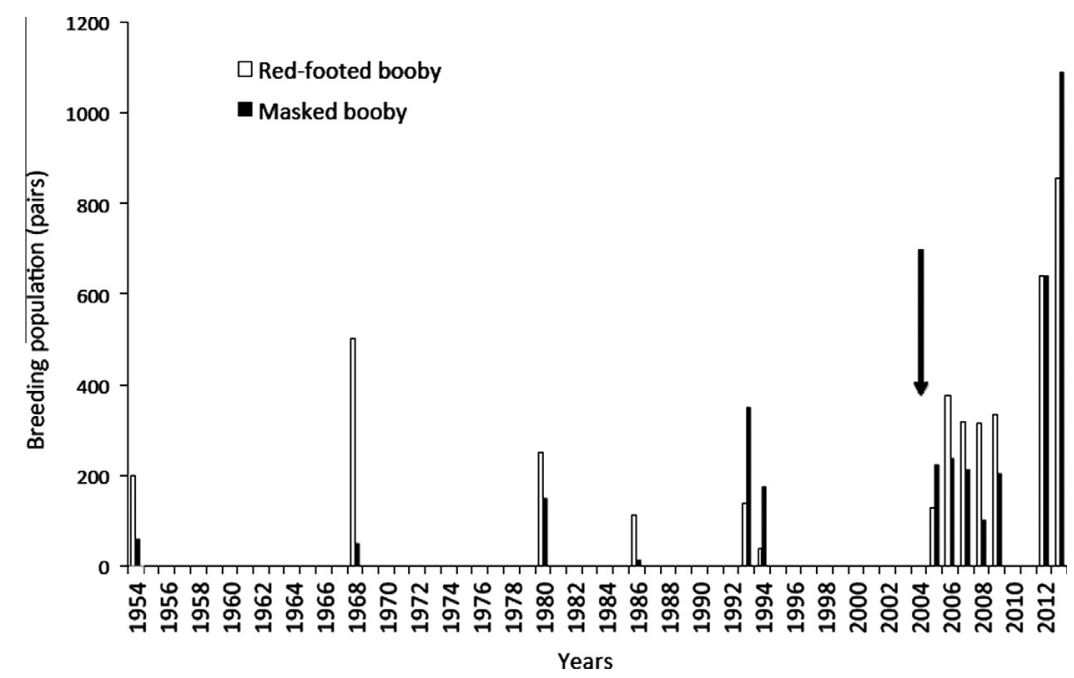

Fig. 2. Trends in numbers of red-footed and masked boobies at Tromelin Island. The arrow indicates the time of rat eradication.
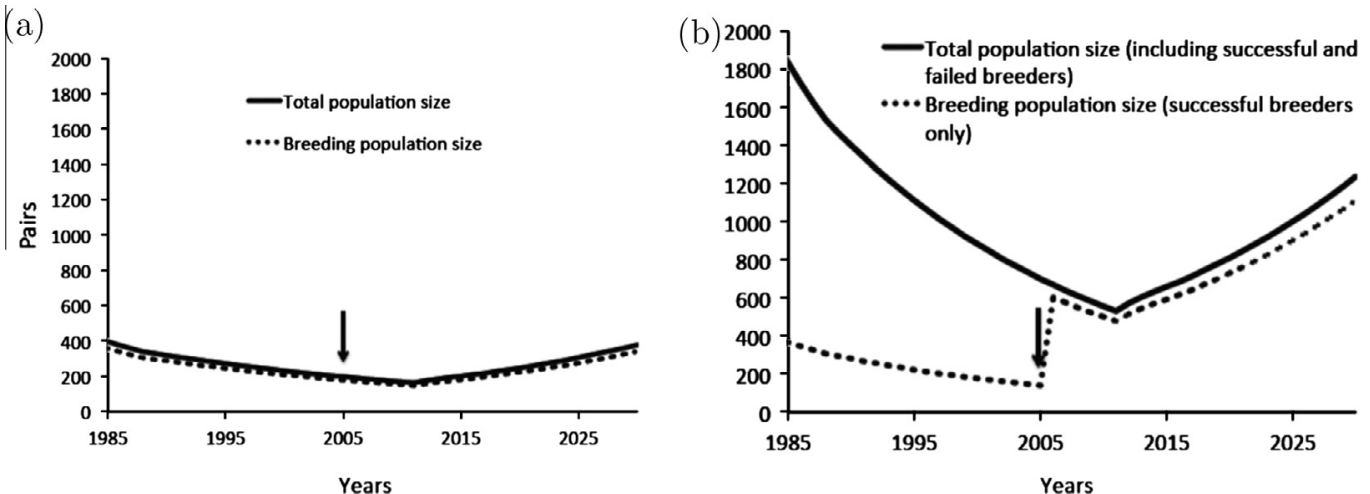

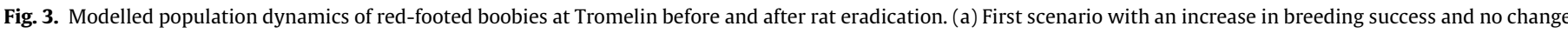

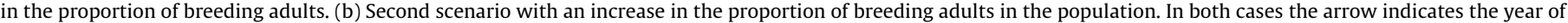
rat eradication.

Table 3

Non-breeding seabirds observed at Tromelin Island in April-May 2013 and August 2013.

\begin{tabular}{|c|c|c|c|}
\hline Species & Period of sightings & Numbers & Comments \\
\hline Great frigatebirds Fregata minor & April-May 13 & $<10$ & Roosting at night \\
\hline Lesser frigatebirds $F$. ariel & April-May 13 & $<10$ & Roosting at night \\
\hline White-tailed tropicbird Phaethon lepturus & 19 and 23 April 13 & 1 & Circling over the island \\
\hline Red-tailed tropicbird $P$. rubricauda & 18 April and 5 May 13 & 1 & Circling over the island \\
\hline Brown booby Sula leucogaster & 16-22 May & 1 & A subadult sitting among masked boobies \\
\hline Sooty tern Onychoprion fuscatus & April - May 13 & $<10$ & Flying over the island. No landing \\
\hline Bridled tern Onychoprion anaethetus & 27 April 13 & 2 & Flying over the island. No landing \\
\hline Brown noddy Anous stolidus & April-May 13 & $<100$ & Roosting at night \\
\hline Lesser noddy Anous tenuirostris & April-May 13 & $>500$ & Roosting at night \\
\hline Roseate tern Sterna dougalli & 17 and 19 April 13 & 2 & Adults in breeding plumage, roosting \\
\hline White tern ${ }^{a}$ Gygis alba & August 13 & 12 & Adults displaying and roosting on shrubs at night \\
\hline
\end{tabular}

${ }^{\text {a }}$ Luc Gigord (personal communication).

2014 (during the revision of a first draft of this manuscript). On 24 August 2014, 30 white terns were observed opportunistically during a one-day logistical stopover on the island, among which 3 pairs were breeding on shrubs of $T$. argentea ( 2 pairs with a near-fledged chick and 1 pair with a half-grown chick) (Regis Perdriat, TAAF, pers. com.). On 26 October 2014 an adult brown booby was also observed incubating two eggs during another stopover on the island (Cédric Marteau, TAAF, pers. com.).

\subsection{Changes in vegetation cover}

No changes to shrub cover were recorded in our designated permanent plots during the study period. However, significant changes to herb cover were reported from certain areas of the island (Figs. 4 and 5). The six plots located at the edge of the island, on rocky areas with an herbaceous vegetation cover of less than $30 \%$ in December 2005, did not change in vegetation cover. 


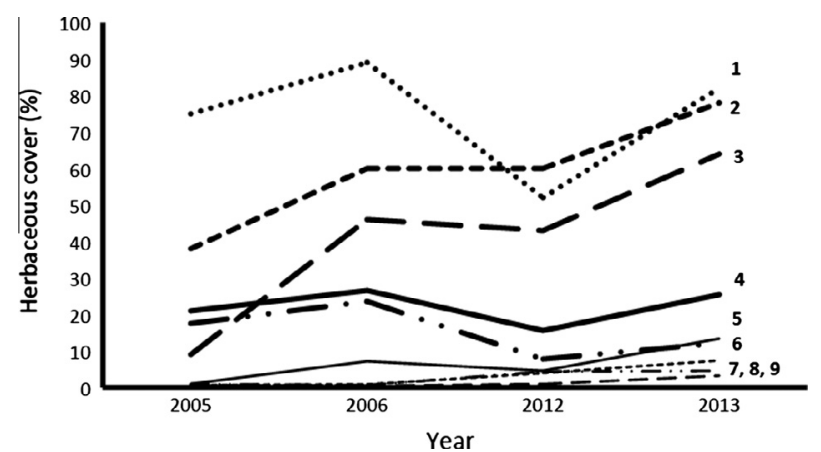

Fig. 4. Changes in vegetation cover from 2005 to 2013. The figures on the right of the lines indicate the number of the permanent plots represented in Fig. $1 \mathrm{~b}$.

Two plots located in the central sandy part on the island had a dramatic increase in herbaceous cover (from 10\% to $60 \%$ for one plot and from $40 \%$ to $80 \%$ for the other, Fig. 4). This increase was due to the spread of a single patch of one herb species, Boerhavia diffusa, a nitrophilous Nyctaginaceae already present before rat eradication (Fig. 5). Finally one plot located in the single patch of $B$. diffusa in December 2005, had a very high herbaceous cover in December 2005 (>70\%) and remained that way (and composed exclusively of B. diffusa) in May 2013 (>80\%).

\section{Discussion}

\subsection{Rat eradication success, mouse eradication failure and possible mouse population release}

Among rodent eradications conducted on islands worldwide, the eradications of Norway rats from small islands ( $<100 \mathrm{ha}$ ) have the highest success rate (Howald et al., 2007). Tromelin is small in size, flat and has no dense vegetation, so all parts of the island were accessible and bait stations were positioned evenly. Furthermore by using "hermit crab proof bait stations," we decreased the risk that hermit crabs consume our baits before rats and thus increased our chance of success (see also Wegmann 2008).
Mouse eradication is known to be more difficult, however (Howald et al., 2007; MacKay et al., 2007), and the reasons for this are related to inadequate bait density relative to the small home range of mice and to the specific foraging behaviour of mice that make them less prone to consume a bait (Howald et al., 2007). In our case, inadequate bait density may have contributed to the failure of mice eradication. The grid size that we used for our "hermit crab proof bait stations" $(100 \times 100 \mathrm{~m})$ would have been too large for mice, resulting in some mouse territories having no bait station. Indeed the width of a mouse territory has been estimated with the mark recapture data as between $75 \mathrm{~m}$ and $100 \mathrm{~m}$ at Tromelin Is. Furthermore, as rats and mice were initially present at the same time during the eradication campaign, rats may have monopolised most poison during the first days of the campaign and this may have reduced the availability of poison for mice. Finally, considering the hand broadcasted baits, it is possible that the hermit crabs and rats monopolised these baits before mice had the opportunity to consume them.

Seasonal changes in the density of mice were recorded on Tromelin Island between August 2012 and May 2013. Rodents are known to undergo such changes in relation to rainfall, especially on tropical islands (Russell et al., 2011; Harper et al., 2015), where vegetation growth is strongly driven by seasonal precipitation (Mueler-Dombois and Fosberg, 1998). Studies of mouse density on tropical islands are rare and this limits inter-island comparisons. Russell et al., (2011) investigated spatial and seasonal variation in mouse density at Juan de Nova (a small coralline island of the central Mozambique Channel), using the same methodology as ours. Mice coexist with black rats (Rattus rattus) and cats (Felis catus) on Juan de Nova, but rats and cats are more abundant in forest than in savannah and rats are more abundant in summer than in winter (Russell et al., 2011). Russell et al., (2011) found that mice were very rare in the forest, especially in summer, but very abundant in the savannah all year round. This suggests that rats (and possibly cats) were limiting mice in the forest but not in the savannah. Interestingly our estimates of mouse density at Tromelin were very similar to those found in the savannah of Juan de Nova (Russell et al., 2011). We lack data on mouse density at Tromelin, before rat eradication, so we cannot ascertain if the current mouse density is due to the absence of rats or not. (a)
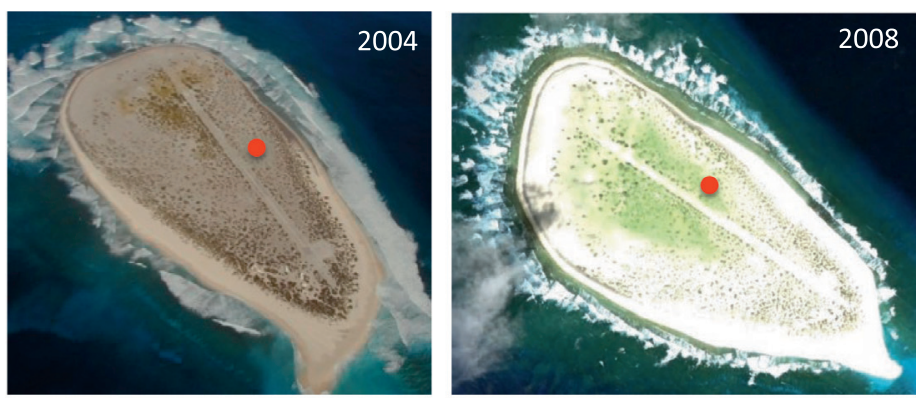

(b)

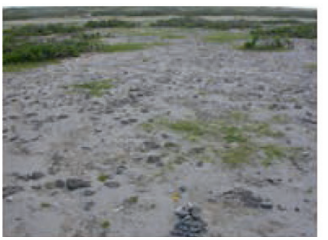

December 2005

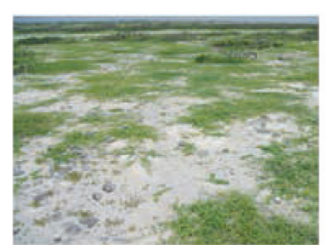

December 2006

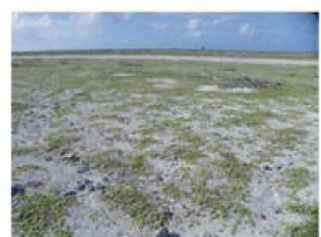

August 2012

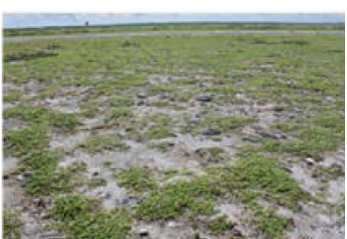

May 2013

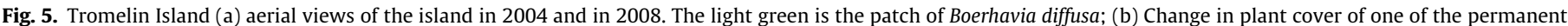

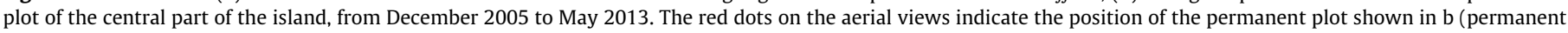
plot no. 3 in Fig. 1b). (For interpretation of the references to colour in this figure legend, the reader is referred to the web version of this article.) 


\subsection{Seabird recovery}

Several studies have shown that seabird populations can recover rapidly after rodent eradication (see for instance Lorvelec and Pascal 2005; Whitworth et al., 2005; Smith et al., 2006; Bellingham et al., 2010; Bourgeois et al., 2013).

In our case, the number of breeding pairs of both species of boobies increased very rapidly after rat eradication. This could be due to an increased immigration or to an increased auto-recruitment. There are six breeding colonies of red-footed boobies and 10 breeding colonies of masked boobies in the western Indian Ocean totalling 37,000 and 13,000 breeding pairs, respectively (Le Corre, unpublished database). Thus there is potential for individual exchanges between colonies of the region, for both species. However, we have no direct evidence of any immigration from other colonies (no recovery of banded birds) and our results on polymorphism of redfooted boobies suggest that, for this species at least, there are very few inter-island exchanges. Both behavioural and population genetic studies have shown that seabirds are highly philopatric and faithful to their breeding place (Friesen et al., 2007). This has been particularly well documented on tropical boobies (Huyvaert and Anderson 2004; Steeves et al., 2005; Morris-Pocock et al., 2010, 2011). All this suggests that the rapid apparent increase in population size is not due to immigration. Alternatively, our modelling approach suggests that such an increase cannot be due solely to an increase of the breeding success followed ( 6 years later) by an increase in recruitment. The observed increase is far higher and quicker than predicted by the model, knowing the life histories of these species.

Our modelling approach has suggested that the increase in number of breeding adults of masked and red-footed boobies may rather be due to an increased proportion of successful breeders in the colony. As already suggested, the breeding success probably increased rapidly after rat eradication, resulting in more breeding adults staying at their breeding places and thus a better detectability of these adults during our snapshot censuses. By modelling this process, we successfully reproduced the rapid increase in number of breeding pairs observed in Tromelin.

Such a rapid dynamic has already been reported at Anacapa Island (California) where Xantus murrelets (Synthliboramphus hypoleucus) were heavily impacted by black rats (Whitworth et al., 2005). A few years after rat eradication, nest occupancies (which is a good proxy of the number of breeding pairs), breeding success, and the surface area of the breeding colony all increased rapidly (Whitworth et al., 2005). The same dynamics occurred at a colony of wedge-tailed shearwaters (Puffinus pacificus) at Mokoli'i Island, O‘ahu, Hawaii, where black rats were removed in 2002 (Smith et al., 2006). Although virtually no breeders reared chicks prior to rat-eradication, 126 pairs (with chicks) were counted in 2002 (just after rat eradication) and 186 were recorded in 2003 (Smith et al., 2006). Similarly, Bourgeois et al., (2013) observed a 10-fold increase, over a two year period, in the number yelkouan shearwaters (Puffinus yelkouan) at Zembretta Island (Tunisia) after rat eradication. These examples (among others) and the dynamics observed at Tromelin Island together suggest that, in seabird colonies heavily impacted by rats, there is often a bulk of breeders, which are initially prevented from breeding successfully because of the presence of rats. These birds can settle and breed successfully soon after rat eradication.

The re-establishment of new breeding seabird species on an island after the eradication of an introduced predator is a longer process, however, because of the specific life history traits of seabirds (low dispersal and high philopatry, Kappes and Jones 2014). The rate of such recovery depends on the numbers of non-breeding birds that prospect the island from other colonies (Jones, 2010a; Rauzon et al., 2011; Buxton et al., 2014). Tromelin is one of the most isolated islands of the tropical Indian Ocean and the nearest source populations are on Saint Brandon $(547 \mathrm{~km})$, Mauritius $(550 \mathrm{~km})$, Réunion $(564 \mathrm{~km})$ and the northern tip of Madagascar $(676 \mathrm{~km})$. However we found a great diversity of seabirds visiting the island, including terns, tropicbirds and frigatebirds. The white tern and the brown booby both started to breed in 2014, some 9 years after rat eradication. The former species was last observed breeding at Tromelin in 1856 (Brooke 1981), but brown booby has, to our knowledge, never bred there before. Most other non-breeding seabird species that occur on the island now are small in size (terns, noddies, tropicbirds), and are highly sensitive to rat predation (Taylor 1979; Van der Elst and Prys Jones 1987; Schaffner 1991; Ringler et al., 2015). We can assume that these sensitive species may start to breed successfully on the island in the near future. Indeed, Rauzon et al., (2011) found that, on Howlands, Baker and Jarvis Islands (equatorial Central Pacific Ocean), seabird diversity and population sizes were returned to historical levels 16 years after cat eradication. Active management using decoys and vocalizations may reduce recovery times (Kappes and Jones 2014).

\subsection{Vegetation changes}

A large patch of the herb $B$. diffusa extended its prior distribution after rat eradication in the central part of the island. This spread may be due to an increase in seedling recruitment after rat eradication, especially at places where the soil is manured by seabird guano. Indeed this patch coincides almost exactly with the current distribution of the increasing colony of masked boobies. The impact of seabird manuring on islands is well documented (Anderson and Polis 1999; Ellis 2005; Jones 2010b) and some soils on islands have even been named "ornithogenic soils" because of the major impacts of seabirds on them (see the review of Ellis 2005). Rats are known to consume vegetation on islands and this has strong effect on plant recruitment (Campbell and Atkinson 2002). B diffusa is a nitrophilous pantropical herb that is known to be eaten by rats (Fleet 1972). This plant has strong adaptation to colonize seabird islands. It produces lots of seeds that are externally transported by seabirds over long distance by viscid adhesion (Aoyama et al., 2012). Also, as a nitrophilous and ruderal herb, $B$. diffusa is known to take advantage of seabird guano (Mueler-Dombois and Fosberg, 1998). Thus it is probable that the eradication of rats on Tromelin led to a better survival of the seedlings and to the extension of the patch.

\subsection{Perspectives}

The recovery of an island after rat eradication is a long process and includes multiple and cascading interactions (see for instance Brodier et al., 2011). It is thus important to investigate post-eradication ecosystem changes in a whole ecosystem context (Zavaleta et al., 2001) and in an ecologically appropriate time frame (Beltran et al., 2014). Our study has shown some rapid changes in seabird abundance and vegetation cover after rat eradication but this dynamic is clearly not completed. Seabird numbers and diversity will probably continue to increase in the future, up to the carrying capacity of the island (in term of space for breeding), and this should have an increasing impact on vegetation cover, on soil structure and on the invertebrate community. There is thus a need for further long-term monitoring of post-eradication changes to better understand these complex interactions (see for instance St Clair 2011, Fukami et al., 2006; Towns et al., 2009). Studies conducted on temperate and sub-antarctic islands have shown that the impacts of mice on plants, invertebrates and birds can be almost as important as those of introduced rats (Angel et al., 2009). The impact of mice on tropical islands is not documented and further long-term studies should be done to investigate it. 


\section{Acknowledgements}

This work was funded by INEE-CNRS (programme MIRE "Mammifères Introduits et Restauration Ecologique"), by the French Agency for Research (ANR ALIENS and ANR REMIGE) and by the French Ministry of Ecology and Environment (programme Biodiversité). Daniel Danckwerts was funded by the South African Research Chairs Initiative of the Department of Science and Technology and the National Research Foundation and received a research travel grant to visit ECOMAR Laboratory by the French Embassy. David Ringler had a Ph-D bursary of the Region Réunion and European Social Funds (FSE). Matthieu Bastien was funded by the Fédération de Recherche "Environnement, Biodiversité, Santé" of the University of Réunion Island. The rat eradication campaign was funded by TAAF and helped by Thierry Perillo, in charge of Iles Eparses. We are grateful to Sandra Blais and Inel Boyer who did the field work during the eradication campaign. We thank Météo-France for providing unpublished information on seabird populations and the Terres Australes et Antarctiques Françaises (especially Cédric Marteau) for their interest in these researches and for providing authorisations and logistical supports. We thank Luc Gigord for providing information on the seabirds he observed during his stay in Tromelin in August 2013. We thank Regis Perdriat, Cédric Marteau and Patrick Payet (TAAF) for providing information on the breeding of white terns and brown boobies in 2014. Finally we thank James Russell, Nick Holmes and three anonymous referees for their constructive comments on earlier drafts of the manuscript.

MLC designated the seabird and plant monitoring protocols, participated in some field work in 2005 and 2006, performed the matrix population modelling and wrote the paper; DD, MB, and CMR did the field work in 2012 and 2013; DR designed the mouse density protocol and analysed the mouse mark-recapture data; SO pre-analysed the seabird and vegetation data; DP did the eradication in 2005 and TM designed the rat and mouse eradication protocol.

\section{Appendix A. Supplementary material}

Supplementary data associated with this article can be found, in the online version, at http://dx.doi.org/10.1016/j.biocon.2014.1 2.015 .

\section{References}

Aguirre-Munoz, A., Croll, D.A., Donlan, C.J., Henry III, R.W., Hermosillo, M.A. Howald, G.R., Keitt, B.S., Luna-Mendoza, L., Rodrıguez-Malagon, M., Salas-Flores, L.M., Samaniego-Herrera, A., Sanchez-Pacheco, J.A., Sheppard, J., Tershy, B.R. Toro-Benito, J., Wolf, S., Wood, B., 2008. High-impact conservation, invasive mammal eradications from the islands of western Mexico. Ambio 37 (2), 101107.

Anderson, W.B., Polis, G.A., 1999. Nutrient fluxes from water to land, seabirds affect plant nutrient status on Gulf of California islands. Oecologia 118, 324-332.

Angel, A., Wanless, R.M., Cooper, J., 2009. Review of impacts of the introduced House Mouse on islands in the Southern Ocean, are mice equivalent to rats? Biol. Invas. 11, 1743-1754.

Aoyama, Y., Kawakami, K., Chiba, S., 2012. Seabirds as adhesive seed dispersers of alien and native plants in the oceanic Ogasawara Islands. Japan. Biodivers. Conserv. 21, 2787-2801.

Bellingham, P.J., Towns, D.R., Cameron, E.K., Davis, J.J., Wardle, D.A., Wilmhurst, J.M., Mulder, C.P.H., 2010. New Zealand island restoration: seabirds, predators, and the importance of history. New Zeal. J. Ecol. 34, 115-136.

Beltran, R.S., Kreidler, N., Van Vuren, D.H., Morrison, S.A., Zavaleta, E.S., Newton, K., Tershy, B.R., Croll, D.A., 2014. Passive Recovery of Vegetation after Herbivore Eradication on Santa Cruz Island. Restoration Ecology, California. http:// dx.doi.org/10.1111/rec.12144.

Bourgeois, K., Ouni, R., Pascal, M., Dromzée, S., Fourcy, D., Abiadh, A., 2013. Dramatic increase in the Zembretta Yelkouan shearwater breeding population following ship rat eradication spurs interest in managing a 1500-year old invasion. Biol. Invas. $15,475-482$.

Borchers, D.L., Efford, M.G., 2008. Spatially explicit maximum likelihood methods for capture-recapture studies. Biometrics 64, 377-385.
Brodier, S., Pisanu, B., Villers, A., Pettex, E., Lioret, M., Chapuis, J.L., Bretagnolle, V., 2011. Responses of seabirds to the rabbit eradication on Ile Verte, sub-Antarctic Kerguelen Archipelago. Anim. Conserv. 14, 459-465.

Brooke, R.K., 1981. Layard' s bird hunting visit to Tromelin or Sandy Island in December 1856. Atoll Res. Bull. 225, 73-82.

Brygoo, E., 1955. Observations sur les oiseaux de Tromelin. Le Naturaliste Malgache 7 (2), 209-214.

Buxton, R.T., Jones, C., Moller, H., Towns, D., 2014. Drivers of seabird population recovery on New Zealand islands after predator eradication. Conserv. Biol. 28, 333-344.

Campbell, D.J., Atkinson, I.A.E., 2002. Depression of tree recruitment by the Pacific rat (Rattus exulans Peale) on New Zealand's northern offshore islands. Biol. Conserv. 107, 19-35.

Caut, S., Casanovas, J.G., Virgos, E., Lozano, J., Witmer, G.W., Courchamp, F., 2007. Rats dying for mice, modelling the competitor release effect. Austral Ecol. 32, $858-868$.

Cubaynes, S., Doherty, P.F., Schreiber, E.A., Gimenez, O., 2011. To breed or not to breed: a seabird's response to extreme climatic events. Biol. Lett. 7, 303-306.

Dearborn, D.C., Anders, A.D., Flint, E.N., 2001. Trends in reproductive success of Hawaiian seabirds, is guild membership a good criterion for choosing indicator species? Biol. Conserv. 101, 97-103.

De Leon, A., Minguez, E., Harvey, P., Meek, E., Crane, J.E., Furness, R.W., 2006. Factors affecting breeding distribution of Storm-petrels Hydrobates pelagicus in Orkney and Shetland. Bird Study 53, 64-72.

Ellis, J.C., 2005. Marine birds on land, a review of plant biomass, species richness, and community composition in seabird colonies. Plant Ecol. 181, 227-241.

Fleet, R.R., 1972. Nesting success of the ed-tailed tropicbird on Kure Atoll. The Auk 89, 651-659.

Friesen, V.L., Burg, T.M., McKoy, K.D., 2007. Mechanisms of population differentiation in seabirds. Mol. Ecol. 16, 1765-1785.

Fukami, T., Wardle, D.A., Bellingham, P.J., Mulder, C.P.H., Towns, D.R., Yeates, G.W., Bonner, K.I., Durrett, M.S., Grant-Hoffman, M.N., Williamson, W.M., 2006. Above- and below-ground impacts of introduced predators in seabirddominated island ecosystems. Ecol. Lett. 9, 1299-1307.

Harper, G.A., Van Dinther, M., Russell, J.C., Bunbury, N., 2015. The response of black rats (Rattus rattus) to evergreen and seasonally arid habitats: informing eradication planning on a tropical island. Biol. Conserv. 185, 66-74.

Holmes, N.D., Griffiths, R., Pott, M., Alifano, A., Will, D., Wegmann A.S., Russell, J.C., 2015. Factors associated with rodent eradication failure. Biol. Conserv. 185, 816.

Howald, G., Donlan, C.J., Galvan, J.G., Russell, J.C., Parkes, J., Samaniego, A., Wang, Y., Veitch, C.R., Genovesi, P., Pascal, M., Saunders, A., Tershy, B., 2007. Invasive rodent eradication on islands. Conserv. Biol. 21, 1258-1268.

Huyvaert, K.P., Anderson, D.J., 2004. Limited dispersal by Nazca boobies Sula granti. J. Avian Biol. 35, 46-53.

Jones, H.P., Tershy, B.R., Zavaleta, E.S., Croll, D.A., Keitt, B.S., Finkelstein, M.E., Howald, G.R., 2008. Severity of the effects of invasive rats on seabirds, a global review. Conserv. Biol. 22, 16-26.

Jones, H., 2010a. Seabird islands take mere decades to recover following rat eradication. Ecol. Appl. 20, 2075-2080.

Jones, H., 2010b. Prognosis for ecosystem recovery following rodent eradication and seabird restoration in an island archipelago. Ecol. Appl. 20, 1204-1216.

Kappes, P.J., Jones, H.P., 2014. Integrating seabird restoration and mammal eradication programs on islands to maximize conservation gains. Biodivers. Conserv. 23, 503-509.

Keitt, B., Griffiths, R., Boudjelas, S., Broome, K., Cranwell, S., Millett, J., Pitt, W., Samaniego-Herrera, A., 2015. Best practice guidelines for rat eradication on tropical islands. Biol. Conserv. 185, 17-26.

Laroulandie, V., Lefevre, C., 2013. The Use of Avian Resources by the Forgotten Slaves of Tromelin Island (Indian Ocean). Int. J. Osteoarcheol. http://dx.doi.org/ $10.1002 /$ oa.2380.

Le Corre, M., 1996. The breeding seabirds of Tromelin Island, western Indian Ocean, population sizes, trends, and breeding phenology. Ostrich 67, 155-159.

Le Corre, M., 1999. Plumage polymorphism of red-footed booby in the western Indian Ocean, an indicator of biogeographic isolation. J. Zool., Lond. 249, 411415.

Legendre, S., Clobert, J., 1995. ULM, a software for conservation and evolutionary biologists. J. Appl. Stat. 122, 817-834.

Lorvelec, O., Pascal, M., 2005. French attempts to eradicate non-indigenous mammals and their consequences for native biota. Biol. Invas. 7, 135-140.

MacKay, J.W.B., Russell, J.C., Murphy, E.C., 2007. Eradicating house mice from islands, successes, failures and the way forward. Manag. Vertebr. Invasive Species 27, 294-304.

Micol, T., Jouventin, P., 2002. Eradication or rats and rabbits from Saint Paul island, French Southern Territories. In: Veicht, C.R. Clout, M.N. (Eds.), Turning the tide, the Eradication of Invasive Species. IUCN SSC Invasive Species Specialist Group, IUCN Gland, Switzerland and Cambridge, UK, pp. 199-205.

Miskelly, C.M., Taylor, G.A., Gummer, H., Williams, R., 2009. Translocations of eight species of burrow-nesting seabirds (genera Pterodroma, Pelecanoides, Pachyptila and Puffinus: Family Procellariidae). Biol. Conserv. 142, 1965-1980.

Morris-Pocock, J.A., Steeves, T.E., Estela, F.A., Anderson, D.J., Friesen, V.L., 2010. Comparative phylogeography of brown (Sula leucogaster) and red-footed boobies ( $S$. sula): the influence of physical barriers and habitat preference on gene flow in pelagic seabirds. Mol. Phylogenet. Evol. 54, 883-896.

Morris-Pocock, J.A., Anderson, D.J., Friesen, V.L., 2011. Mechanisms of global diversification in the brown booby (Sula leucogaster) revealed by uniting 
statistical phylogeographic and multilocus phylogenetics methods. Mol. Ecol. 20, 2835-2850.

Mueler-Dombois, D., Fosberg, F.R., 1998. Vegetation of the Tropical Pacific Islands. Springer-Verlag, New York Inc.

Mulder, C.P.H., Grant-Hoffman, M.N., Towns, D.R., Bellingham, PJ., Wardle, D.A. Durret, M.S., Kukami, T., Bonner, K.I., 2009. Direct and indirect effects of rats: does rat eradication restore ecosystem functioning of New Zealand seabird islands? Biol. Invas. 11, 1671-1688.

Pascal, M., Lorvelec, O., Bretagnolle, V., Culioli, J.M., 2008. Improving the breeding success of a colonial seabird, a cost-benefit comparison of the eradication and control of its rat predator. Endangered Species Res. 4, 267-276.

Rauzon, M.J., Forsell, D.J., Flint, E.N., Gove, J.M., 2011. Howland, Baker and Jarvis Islands 25 years after cat eradication: the recovery of seabirds in a biogeographical context. In: Veitch, C.R., Clout, M.N., Towns, D.R. (eds), 2011. Island invasives: eradication and management. IUCN, Gland, Switzerland, 345349.

Ringler, D., Russell, J.C., Le Corre, M., 2015. Trophic roles of black rats and seabird impacts on tropical islands: mesopredator release or hyperpredation? Biol. Conserv. 185, 75-84.

Ruffino, L., Bourgeois, K., Vidal, E., Duhem, C., Paracuellos, M., Escribano, F., Sposimo, P., Baccetti, N., Pascal, M., Oro, D., 2009. Invasive rats and seabirds after 2000 years of an unwanted coexistence on Mediterranean islands. Biol. Invas. http:// dx.doi.org/10.1007/s10530-008-9394-z.

Ruscoe, W.A., David, S.L., Ramsey, D.S.L., Pech, R.P., Sweetapple, P.J., Yockney, I., Barron, M.C., Perry, M., Nugent, G., Carran, R., Warne, R., Brausch, C., Duncan, R.P., 2011. Unexpected consequences of control, competitive vs, predator release in a four-species assemblage of invasive mammals. Ecol. Lett. 14, 10351042.

Russell, J.C., Le Corre, M., 2009. Introduced mammal impacts on seabirds in the Îles Éparses, Western Indian Ocean. Mar. Ornithol. 37, 121-128.

Russell, J.C., Ringler, D., Trombini, A., Le Corre, M., 2011. The island syndrome and population dynamics of introduced rats. Oecologia 167, 667-676.

Russell, J.C., Holmes, N.D., 2015. Tropical island conservation: rat eradication for species recovery. Biol. Conserv. 185, 1-7.

Schaffner, F.C., 1991. Nest-site selection and nesting success of White-tailed Tropicbird (Phaethon lepturus) at Cayo Luis Pena, Puerto Rico. The Auk 108, 911-922.

Smith, V.R., 1979. The influence of seabird manuring in the phosphorus status of Marion Island (Subantarctic) soils. Oecologia 41, 123-126.
Smith, D.G., Shiinoki, E.K., VanderWerf, E.A., 2006. Recovery of native species following rat eradication on Mokoli'i Island, O‘ahu, Hawai'i. Pac. Sci. 60 (2) 299-303.

Steeves, T.E., Anderson, D.J., Friesen, V.L., 2005. A role for nonphysical barriers to gene flow in the diversification of a highly vagile seabird, the masked Booby (Sula dactylatra). Mol. Ecol. 14, 3877-3887.

Taylor, R.H., 1979. Predation on Sooty Terns at Raoul Island by rats and cats Notornis 26, 199-202.

Thibault, J.C., 1995. Effect of predation by the Black Rat Rattus rattus on the breeding success of Cory's shearwater Calonectris diomeda in Corsica. Mar. Ornithol. 23, $1-10$.

Towns, D.R., Atkinson, I.A.E., Daugherty, C.H., 2006. Have the harmful effects of introduced rats on islands been exaggerated? Biol. Invas. 8, 863-891.

Towns, D.R., Broome, K.G., 2003. From small Maria to massive Campbell, forty years of rat eradications from New Zealand islands. New Zeal. J. Zool. 30, 377-398.

Towns, D.R., Wardle, D.A., Mulder, C.P.H., Yeates, G.W., Fitzgerald, B.M., Parrish, G.R. Bellingham, P.J., Bonner, K.I., 2009. Predation of seabirds by invasive rats: multiple indirect consequences for invertebrate communites. Oikos 118, 420 430.

Van der Elst, R., Prys Jones, R.P., 1987. Mass killing by rats of roosting common noddies. Oryx 21, 219-222.

Varnham, K., 2010. Invasive Rats on Tropical Islands, Their History, Ecology, Impacts and Eradication. Royal Society for the Protection of Birds, Sandy, UK.

Wainright, S.C., Haney, J.C., Kerr, C., Golovkin, A.N., Flint, M.V., 1998. Utilization of nitrogen derived from seabird guano by terrestrial and marine plants at St. Paul, Pribilof Islands, Bering Sea, Alaska. Mar. Biol. 131, 63-71.

Wegmann, A., 2008. Land Crab Interference with Eradication Projects: Phase I Compendium of Available Information. The University of Auckland, New Zealand, Pacific Invasives Initiative.

Whitworth, D.L., Carter, H.R., Young, R.J., Koepke, J.S., Gress, F., Fangman, S., 2005 Initial recovery of Xantus's Murrelets following rat eradication on Anacapa Island, California. Mar. Ornithol. 33, 131-137.

Witmer, G.W., Boyd, F., Hillis-Starr, Z., 2007. The successful eradication of introduced roof rats (Rattus rattus) from Buck Island using diphacinone, followed by an irruption of house mice (Mus musculus). Wildlife Res. 34, 108 115.

Zavaleta, E.S., Hobbs, R.J., Mooney, H.A., 2001. Viewing invasive species removal in a whole-ecosystem context. TREE 16, 454-459. 